Check for updates

Cite this: RSC Adv., 2017, 7, 23560

Received 26th December 2016 Accepted 22nd April 2017

DOI: $10.1039 / c 6 r a 28272 e$

rsc.li/rsc-advances

\section{Titanium dioxide nanoparticles induce size- dependent cytotoxicity and genomic DNA hypomethylation in human respiratory cells}

\begin{abstract}
Yue Ma, (D) † Yinsheng Guo, (D) † Shuang Wu, Ziquan Lv, Qian Zhang and Yuebin Ke (D) *
The widespread use of titanium dioxide nanoparticles $\left(\mathrm{TiO}_{2} \mathrm{NPS}\right)$ is gradually increasing the risk of exposure to these potentially hazardous materials. Although numerous health effects of $\mathrm{TiO}_{2} \mathrm{NPs}$ have been investigated, it remains unknown whether they could affect the respiratory cellular epigenome. We explored the viability, membrane integrity, intracellular ROS and genomic DNA methylation of human respiratory cells, as well as their expression of methylation-related genes, after treatment with $\mathrm{TiO}_{2} \mathrm{NPs}$ with diameters of $25 \mathrm{~nm}$ (nanotube morphology) or $60 \mathrm{~nm}$ (anatase morphology). Two cell lines relevant to inhalation exposure, namely human bronchial epithelial cell line (16HBE) and human non-small cell lung cancer cells (A549), were tested, with treatment concentrations ranging from 0.1 to $100 \mu \mathrm{g} \mathrm{m}^{-1}$. The $\mathrm{TiO}_{2}$ NPs induced time- and concentration-dependent decreases in cell viability in both A549 and $16 \mathrm{HBE}$ cells. The reduction in cell viability was greater for the smaller particles (size $25 \mathrm{~nm}$ ) of the nanotube type. Cellular membrane integrity assays revealed that $16 \mathrm{HBE}$ cells were less sensitive to $\mathrm{TiO}_{2}$ NPs-25 nm (nanotube-type) than were A549 cells, as higher concentrations were required for cytotoxicity against the former. $\mathrm{TiO}_{2} \mathrm{NPs}-25 \mathrm{~nm}$ (nanotube-type) showed greater toxicity against both cell lines than $\mathrm{TiO}_{2}$ NPs-60 nm (anatase-type). Intracellular ROS levels in both A549 and 16HBE cell were increased by $\mathrm{TiO}_{2} \mathrm{NPs}$ whereas pretreatment with the antioxidant $\mathrm{N}$-acetyl-L-cysteine eliminated $\mathrm{TiO}_{2}$ NPs-induced ROS accumulation and reduced cell death. Moreover, the anatase-type $\mathrm{TiO}_{2} \mathrm{NPs}_{\text {resulted }}$ in decreased global DNA methylation and altered expression levels of methylation-related genes and proteins, suggesting that these NPs induce cellular epigenomic toxicity. These results allowed us to confirm the epigenetic mechanism by which $\mathrm{TiO}_{2} \mathrm{NPs}$ damage human respiratory cells.
\end{abstract}

\section{Introduction}

In recent decades, titanium dioxide nanoparticles $\left(\mathrm{TiO}_{2} \mathrm{NPs}\right)$ have been mass-produced for their worldwide applications in food-related industries, materials for air pollution control, pharmaceuticals and personal care products. ${ }^{1}$ The extensive production and use of $\mathrm{TiO}_{2}$ NPs has increased the level of human exposure through multiple media and pathways. $\mathrm{TiO}_{2}$ NPs can be delivered directly into the human body as nano-food or nanomedicine. ${ }^{2}$ Due to their small particle size, industrially released $\mathrm{TiO}_{2}$ NPs can also be inhaled as airborne particulate matter. ${ }^{3}$ Concerns are increasing about the possible health implications of exposure to $\mathrm{TiO}_{2} \mathrm{NPs}^{4,5}$

Increasing number of evidence has shown that $\mathrm{TiO}_{2} \mathrm{NPs}$ exert a variety of adverse health effects including liver function damage, nephrotoxicity and pulmonary toxicity ${ }^{6-8}$ Both in vitro

Key Laboratory of Molecular Biology, Key Laboratory of Genetics \& Molecular Medicine of Shenzhen, Shenzhen Center for Disease Control and Prevention, No 8 Longyuan Road, Nanshan District, Shenzhen 518055, China. E-mail: keyke@szu.edu.cn; Fax: +86-755-25531876; Tel: +86-755-25531876

$\dagger$ Both authors contributed equally to this work. and in vivo toxicological assays have characterised the harmful effects of $\mathrm{TiO}_{2}$ NPs on organs and tissues, especially in the respiratory system. For example, a study on mice indicated that nano- $-\mathrm{TiO}_{2}$ could induce severe pulmonary emphysema, extensive disruption of alveolar septa and type II pneumocyte hyperplasia. ${ }^{8}$ Inhalation of nano- $\mathrm{TiO}_{2}$ was found to provoke lung inflammation in mice via the biological activity of IL-1 $\alpha .{ }^{9}$ Additionally, in vitro assays showed that $\mathrm{TiO}_{2}$ NPs elicited distinct apoptotic pathways in bronchial epithelial cells through lysosomal membrane destabilisation and lipid peroxidation. ${ }^{10}$ Oxidative stress was also detected in human pulmonary epithelial cells after exposure to $\mathrm{TiO}_{2} \mathrm{NPs}^{11}$

To extend current knowledge, further study is required of the possible epigenetic effects of $\mathrm{TiO}_{2}$ NPs on respiratory cells. At present, the genomic toxicity of $\mathrm{TiO}_{2} \mathrm{NPs}$ and their ability to affect the cellular epigenome of human respiratory cells remain largely unexplored. It is generally accepted that epigenetic factors regulate the interplay between genes and the environment, and thus affect human diseases. ${ }^{12}$ Additionally, epigenetic alterations in airway cells have been found to be associated with respiratory diseases. ${ }^{13}$ Multiple studies have found evidence that DNA methylation plays a role in human 
respiratory diseases. ${ }^{\mathbf{1 4 , 1 5}}$ Therefore, $\mathrm{TiO}_{2}$ NPs may have epigenetic effects on human respiratory cells.

Epigenetic effects are heritable changes, caused by environmental factors, that regulate gene expression via alterations in chromatin proteins without changes in DNA sequences. ${ }^{16}$ DNA methylation is a major epigenetic modification that can regulate gene expression. ${ }^{17}$ Aberrant DNA methylation has been demonstrated in a variety of diseases. ${ }^{18}$ Genomic DNA methylation is catalysed by the activities of methylation enzymes, including DNA methyltransferase 1 (DNMT1), DNMT3a and DNMT3b. Ten-eleven translocation (TET) proteins catalyse the hydroxymethylation step in the DNA demethylation pathway. ${ }^{19}$ Methyl-CpG-binding domain protein 2 (MBD2), with its ability to bind to methylated DNA, appears to function as a mediator of the biological consequences of the methylation signal. ${ }^{20}$ Numerous studies have indicated that exposure to nanoparticles can compromise the DNA methylome. For example, exposure of human small-airway epithelial cells to engineered nanoparticles emitted by laser printers was found to result in alterations in both global DNA methylation patterns. ${ }^{21}$ Short-term exposure to engineered nanomaterials was also found to affect the epigenome of macrophages and airway epithelial cells. ${ }^{22}$ Another study found that multi-walled carbon nanotubes could induce DNA hyper-methylation. ${ }^{23}$ Taken together, these studies confirm the epigenetic effects of nanoparticles and highlight the importance of DNA methylation in the study of nanoparticle toxicity. In this context, $\mathrm{TiO}_{2}$ NPs of different diameters and crystal forms may represent a new set of tools to study the influence of nanoscale geometry on cell behaviour. ${ }^{24,25}$

In this study, the biological responses of human respiratory cells exposed to $\mathrm{TiO}_{2}$ NPs were evaluated across a wide range of exposure doses. $\mathrm{TiO}_{2}$ NPs with two different diameters $(25 \mathrm{~nm}$ and $60 \mathrm{~nm}$ ) and of nanotube or anatase type were used to investigate the influence of particle size and crystal form. The methylation status of genomic DNA and the expression of Dnmt3b, TETs and $M b d 2$ in the treated cells were also assessed.

\section{Materials and methods}

\section{Chemicals}

Titanium dioxide nanotubes of $25 \mathrm{~nm}$ average diameter $\left(\mathrm{TiO}_{2}\right.$ N25) were purchased from Sigma-Aldrich (St. Louis, MO, USA). Anatase $\mathrm{TiO}_{2}$ of $60 \mathrm{~nm}$ average diameter $\left(\mathrm{TiO}_{2}-\mathrm{A} 60\right)$ was purchased from Aladdin (Shanghai, China). A stock suspension of $\mathrm{TiO}_{2}$ NPs at a concentration of $10 \mathrm{mg} \mathrm{mL}^{-1}$ was prepared in cell culture media and ultra-sonicated for $10 \mathrm{~min}$. The $\mathrm{TiO}_{2} \mathrm{NPs}$ were further diluted in cell culture media to $0.1,1,10$ and $100 \mu \mathrm{g}$ $\mathrm{mL}^{-1}$ and sonicated within $5 \mathrm{~min}$ before the treatment.

Dimethylsulphoxide (DMSO) and $N$-acetyl-L-cysteine (NAC) were also obtained from Sigma-Aldrich (St. Louis, MO, USA). NAC was used at $3 \mathrm{mmol} \mathrm{L}^{-1}$ and added $1 \mathrm{~h}$ before $\mathrm{TiO}_{2}$ NPstreatment. Trypsin and a penicillin-streptomycin mixture for cell culture were purchased from Hyclone Laboratories, Inc. (Logan, UT, USA). Roswell Park Memorial Institute (RPMI) 1640 medium, minimum essential Eagle's medium (MEM) and foetal bovine serum (FBS) were purchased from Gibco (Carlsbad, CA, USA). A PrimeScript 1st Strand cDNA Synthesis Kit was purchased from Takara Biotechnology (Dalian, China).

\section{2. $\mathrm{TiO}_{2} \mathrm{NP}$ characterisation}

The $\mathrm{TiO}_{2}$ NP stock suspensions were diluted in water and sonicated for $60 \mathrm{~s}$ at $60 \mathrm{~W}$ (Bioblock ultrasonic processor 75038, Bioblock Scientific, Illkirch, France) for preparation. The size and shape of the $\mathrm{TiO}_{2}$ NPs were determined using a scanning electron micrographs (SEM, S-4800, Hitachi, Tokyo, Japan). The hydrodynamic diameter and zeta potential of the $\mathrm{TiO}_{2} \mathrm{NPs}$ were determined by dynamic light scattering (Brookhaven 90 Plus, Brookhaven Instruments Co, NY, USA). Measurements were run in triplicate for each sample.

\section{Cell culture}

The human bronchial epithelial cell line 16HBE was kindly provided by Prof. D. C. Gruenert (University of California, CA, USA). The human non-small cell lung cancer cell line A549 was obtained from the Type Culture Collection of the Chinese Academy of Sciences (Shanghai, China). The 16HBE cells were cultured in fresh MEM supplemented with $10 \%$ (v/v) FBS, 100 $\mu \mathrm{g} \mathrm{mL}^{-1}$ penicillin and $100 \mu \mathrm{g} \mathrm{mL}^{-1}$ streptomycin in a cell culture flask in an atmosphere containing $5 \% \mathrm{CO}_{2}$ at $37^{\circ} \mathrm{C}$ in an incubator. The A549 cells were cultured in fresh RPMI 1640 medium containing $10 \%(\mathrm{v} / \mathrm{v}) \mathrm{FBS}, 100 \mu \mathrm{g} \mathrm{mL} \mathrm{m}^{-1}$ penicillin and $100 \mu \mathrm{g} \mathrm{mL}{ }^{-1}$ streptomycin.

The culture medium was changed every $48 \mathrm{~h}$, and the cells were subcultured every 3 to 4 days at approximately $80 \%$ confluence. When the cultured cells had grown to about $80 \%$ confluence, the cultures were treated with $\mathrm{TiO}_{2}-\mathrm{N} 25$ or $\mathrm{TiO}_{2}-\mathrm{A} 60$ at different concentrations $\left(0.1,1,10\right.$ and $\left.100 \mu \mathrm{g} \mathrm{mL}^{-1}\right)$ for $48 \mathrm{~h}$, and the control cells were cultured with regular culture medium without $\mathrm{TiO}_{2}$ NPs.

\section{Cell viability assay}

The cell viability of the $16 \mathrm{HBE}$ and A549 cells after treatment with $\mathrm{TiO}_{2}$ NPs was tested by 3-(4,5-dimethylthiazol-2-yl)-2,5diphenyltetrazolium bromide (MTT) assay. The cells were plated on 96-well plates at a density of $4 \times 10^{4}$ cells per $\mathrm{mL}$ and then incubated for $24 \mathrm{~h}$. Different concentrations of $\mathrm{TiO}_{2}-\mathrm{N} 25$ or $\mathrm{TiO}_{2}$-A60 (in the range $0.1-100 \mu \mathrm{g} \mathrm{mL}^{-1}$ ) were added into the cell culture and incubation was continued for 24-72 h. Wells containing culture medium but no cells were used as the blank, and wells containing culture medium without $\mathrm{TiO}_{2}$ NPs treatment were used as the control. After adding $20 \mu \mathrm{L}$ of MTT $(5 \mathrm{mg}$ $\mathrm{mL}^{-1}$ ) into each well and incubating for $4 \mathrm{~h}$ at $37{ }^{\circ} \mathrm{C}$, the MTT medium was discarded and the cells were lysed in $100 \mu \mathrm{L}$ of DMSO. The optical density (OD) at $490 \mathrm{~nm}$ was measured by a multiwell-plate reader (Bio-Tek EL 808, Bio-Tek Instruments Inc, Colmar, France). Cell viability values (\%), expressed as the percentage of absorbance values at each dose compared to the vehicle control, were calculated by $\left(\mathrm{OD}_{\mathrm{TiO}_{2}} \mathrm{NPs}-\mathrm{OD}_{\text {blank }}\right) /$ $\left(\mathrm{OD}_{\text {control }}-\mathrm{OD}_{\text {blank }}\right) \times 100 \%$.

\section{Cellular membrane integrity assay}

Cellular membrane integrity was evaluated using the CytoToxOne Homogenous Membrane Integrity Assay (Promega, Madison, WI, USA) following exposure to different concentrations of 
$\mathrm{TiO}_{2}-\mathrm{N} 25$ or $\mathrm{TiO}_{2}-\mathrm{A} 60\left(0.1-100 \mu \mathrm{g} \mathrm{mL}^{-1}\right)$ for 24,48 and $72 \mathrm{~h}$. This assay was performed to estimate the number of non-viable cells present after exposure to $\mathrm{TiO}_{2}$ NPs by measuring the activity of lactate dehydrogenase $(\mathrm{LDH})$ leaked from the cells.

\section{Determination of the intracellular reactive oxygen species (ROS) content}

The ROS content generated in the $16 \mathrm{HBE}$ and A549 cells was measured by the oxidant-sensitive probe DCFH-DA according to the manufacturer's instructions (Beyotime, Shanghai, China). Briefly, the cells were treated with different concentrations of $\mathrm{TiO}_{2}$ NPs (N25 or A60 in the range $0.1-100 \mu \mathrm{g} \mathrm{mL}{ }^{-1}$ ) or cotreatment with NAC for $48 \mathrm{~h}$ and then stained with DCFH-DA $10 \mu \mathrm{M}$ at $37{ }^{\circ} \mathrm{C}$ for $20 \mathrm{~min}$. The cells were rinsed and imaged by using the fluorescence microscope (Olympus, Tokyo, Japan) at $488 \mathrm{~nm}$ for excitation. The fluorescence intensities of DCFHDA in the cells were analyzed using Image-Pro Plus software (Media Cybernetics, Silver Spring, MD, USA).

\section{Analysis of genomic DNA methylation}

Genomic DNA from the $16 \mathrm{HBE}$ and A549 cells was extracted using a Wizard Genomic DNA Purification Kit (Promega, Madison, WI, USA). Genomic DNA methylation was determined by a MethylFlash Methylated DNA Quantification Kit (Epigentek, Brooklyn, NY, USA) according to the manufacturer's instructions.

\section{RNA isolation and quantitative real-time PCR (Q-PCR)}

Total cellular RNA was isolated from the cells using Trizol reagent (Invitrogen, Carlsbad, CA, USA). Reverse transcription for cDNA synthesis was performed using Revert Aid First Strand cDNA Synthesis Kits (Fermentas, Hanover, MD, USA). Quantifications of gene transcripts were performed by Q-PCR on the 7900HT fast real-time PCR system (Applied Biosystems, Foster City, CA, USA) using SYBR Green PCR Master Mix reagents (Applied Biosystems, Framingham, MA, USA). Samples were analysed in triplicate. The Q-PCR cycle conditions were $95{ }^{\circ} \mathrm{C}$ for $2 \mathrm{~min}$, followed by 40 cycles of denaturation at $95^{\circ} \mathrm{C}$ for $15 \mathrm{~s}$ and annealing and extension at $60{ }^{\circ} \mathrm{C}$ for $1 \mathrm{~min}$. The relative gene expression values were calculated by the $2^{-\Delta \Delta C_{\mathrm{t}}}$ method and normalised to values obtained from the housekeeping gene GAPDH. Three independent experiments were performed for each target. Primer sequences for Q-PCR are listed in Table 1.

\section{Western blot analysis}

The total proteins in the $16 \mathrm{HBE}$ and A549 cells were extracted using radio-immunoprecipitation assay (RIPA) lysis buffer (Beyotime, Shanghai, China) containing $1 \mathrm{mM}$ phenylmethanesulfonyl fluoride (Sigma-Aldrich, St. Louis, MO, USA). The concentrations of total protein were determined by BCA protein assay kits (Beyotime, Jiangsu, China). Total proteins from each group were separated by a $12 \%$ denaturing polyacrylamide gel. The blotted membranes were blocked using 5\% (w/v) non-fat milk in Tris-buffered saline (TBS) and incubated with anti- $\beta$-actin, anti-DNMT3B or MBD2 1 : 1000, Abcam, Cambridge, UK) for $2 \mathrm{~h}$ at $37{ }^{\circ} \mathrm{C}$. The membranes were
Table 1 Primer sequences for real-time PCR

\begin{tabular}{lll}
\hline Gene & Primer sequence $\left(5^{\prime}-3^{\prime}\right)$ & Accession number \\
\hline Gapdh & $\begin{array}{l}\text { Forward: AACGACCCCTTCATTGAC } \\
\text { Reverse: TCCACGACATACTCAGCAC }\end{array}$ & NM_001256799.2 \\
Dnmt3b & $\begin{array}{l}\text { Forward: CCGCTTCCTCGCAGCAG } \\
\text { Reverse: TGGGCTTTCTGAACGAGTCC }\end{array}$ & NM_001207055.1 \\
Mbd2 & $\begin{array}{l}\text { Forward: GGGAAGAGGATGGATTGCCC } \\
\text { Reverse: AGCTGACGTGGCTGTTCATT }\end{array}$ & NM_003927.4 \\
Tet1 & $\begin{array}{l}\text { Forward: CCAAGTCATGCAGCCCTACC } \\
\text { Reverse: CACAAGGTTTGGTCGCTGG }\end{array}$ & XM_011540204.1 \\
Tet2 & $\begin{array}{l}\text { Forward: CCCGCTGAGTGATGAGAACA } \\
\text { Reverse: TGTGCTGCTGAATGTTTGCC }\end{array}$ & NM_001127208.2 \\
Tet3 & $\begin{array}{l}\text { Forward: ACCTGCCAGGCCTTTATGAC } \\
\text { Reverse: ACCACACCGTTTCCGTTTCT }\end{array}$ & NM_001287491.1 \\
& &
\end{tabular}

incubated with secondary antibody (LI-COR Bioscience, Lincoln, NE, USA) and the protein bands were visualized using an enhanced chemiluminescence method, and then quantified by Image $\mathrm{J}$.

\section{Statistical analysis}

Data are expressed as means \pm SD. Statistical analysis was performed using SPSS 13.0 (SPSS Inc., Chicago, IL, USA). Comparisons between all cellular parameters after exposure were performed using one-way analysis of variance and the Tukey correction for multiple-comparison statistical significance. A $P$ value $<0.05$ was considered to be statistically significant. All experiments were independent and conducted in triplicate or more.

\section{Results}

\section{1. $\mathrm{TiO}_{2} \mathrm{NP}$ characterization}

The $\mathrm{TiO}_{2}$ NPs (of the nanotube type with particle size of $25 \mathrm{~nm}$, or of the anatase type with particle size of $60 \mathrm{~nm}$ ) were characterized for their size, shape, hydrodynamic diameter and zeta potential before cell culture experimentation. The SEM images of $\mathrm{TiO}_{2}$ NPs were shown in Fig. 1 which confirmed the size and shape described by Sigma-Aldrich and Aladdin. Physicochemical characteristics (diameter, zeta potentials and hydrodynamic diameters of the suspended particles in water and culture mediums) of the $\mathrm{TiO}_{2}$ NPs are given in Table 2. Both types of $\mathrm{TiO}_{2}$ NPs showed negative zeta potentials in all media. In both MEM and RPMI 1640 culture mediums, the $\mathrm{TiO}_{2}-\mathrm{A} 60$ particles showed less negative surface charge than $\mathrm{TiO}_{2}-\mathrm{N} 25$. The analysis of the hydrodynamic diameters showed that both types of $\mathrm{TiO}_{2}$ NPs formed small aggregates in water, RPMI 1640 and MEM suspension. $\mathrm{TiO}_{2}-\mathrm{N} 25$ presents a population of aggregates with a mean particle size of $125 \mathrm{~nm}$ in water, $372 \mathrm{~nm}$ in RPMI 1640 and $254 \mathrm{~nm}$ in MEM. In water, the $\mathrm{TiO}_{2}-\mathrm{A} 60$ particles formed one population of smaller aggregates $(51 \mathrm{~nm})$ and another population of larger ones $(320 \mathrm{~nm}) . \mathrm{TiO}_{2}-\mathrm{A} 60$ also formed both smaller and larger aggregates in RPMI 1640 and MEM, with size distributions of 86 and $620 \mathrm{~nm}$, and 101 and $620 \mathrm{~nm}$, respectively. 
A

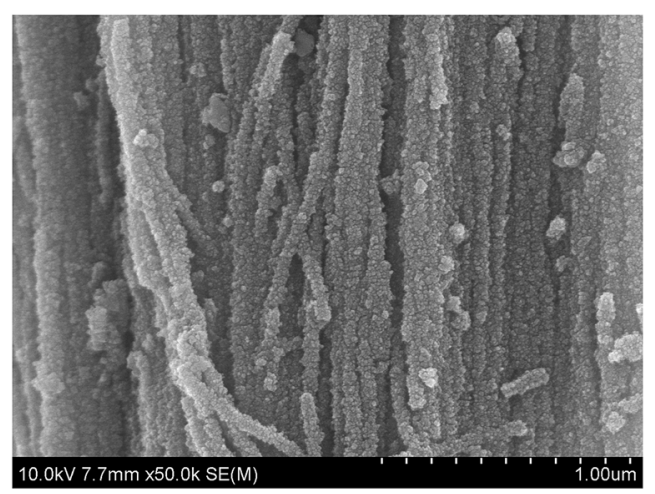

B

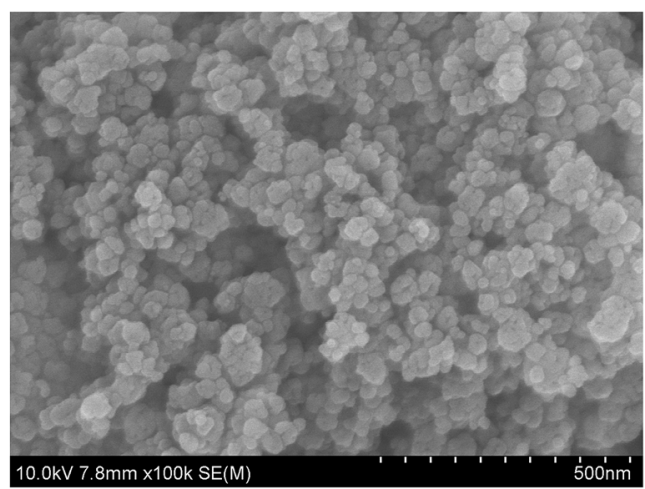

Fig. 1 (A) SEM images of $\mathrm{TiO}_{2}-\mathrm{N} 25$. (B) SEM images of $\mathrm{TiO}_{2}-\mathrm{A} 60$.

Table 2 Physico-chemical characteristics of titanium dioxide nanoparticles

\begin{tabular}{|c|c|c|c|c|c|c|c|c|c|}
\hline & Diameter & $\begin{array}{l}\text { Average SEM size } \\
(\mathrm{nm} \pm \mathrm{SD})\end{array}$ & \multicolumn{3}{|c|}{ Zeta potential $(\mathrm{mV})$} & \multicolumn{3}{|c|}{ Hydrodynamic diameter $(\mathrm{nm})$} & $\begin{array}{l}\text { Crystalline } \\
\text { structure }\end{array}$ \\
\hline $\mathrm{TiO}_{2}-\mathrm{A} 60$ & $60 \mathrm{~nm}$ & $51.9 \pm 8.7$ & -13.1 & -7.6 & -6.4 & 51 and 320 & 86 and 572 & 101 and 620 & Anatase \\
\hline
\end{tabular}

\section{Effects of $\mathrm{TiO}_{2}$ NP exposure on cell viability}

To investigate whether the $\mathrm{TiO}_{2}$ NPs exerted cytotoxic effects on the A549 and 16HBE cells, the cell viabilities were determined by MTT after 24, 48 and $72 \mathrm{~h}$ of treatment. We observed distinct cellular responses to the two types of $\mathrm{TiO}_{2} \mathrm{NP}$. As shown in Fig. 2A, the cell viabilities of the A549 cells significantly decreased $(P<0.05)$ after exposure to either $\mathrm{TiO}_{2}-\mathrm{N} 25$ or $\mathrm{TiO}_{2}$ A60 at concentrations of $1-100 \mu \mathrm{g} \mathrm{mL}^{-1}$ for $24 \mathrm{~h}$. For the $16 \mathrm{HBE}$ cells, $\mathrm{TiO}_{2}-\mathrm{N} 25$ inhibited the cell viabilities (compared with the control) at all concentrations in the range $1-100 \mu \mathrm{g} \mathrm{mL}^{-1}$ after $24 \mathrm{~h}$ treatment (Fig. 2B, $P<0.05$ ). However, $24 \mathrm{~h}$ treatment with $\mathrm{TiO}_{2}$-A60 caused a significant decrease in the cell viabilities of the $16 \mathrm{HBE}$ cells only at concentrations of 10 and $100 \mu \mathrm{g} \mathrm{mL} \mathrm{m}^{-1}$. For longer treatment times ( 48 and $72 \mathrm{~h}$ ), the decrease in cell viability increased with each increment of the treatment time. The cell viability of both cell lines decreased more strongly with higher treatment concentrations, longer treatment times and smaller particle sizes.

\section{Effects of $\mathrm{TiO}_{2} \mathrm{NP}$ exposure on cellular membrane integrity}

The cellular membrane integrity of the $16 \mathrm{HBE}$ and A549 cells was tested after treatment with $\mathrm{TiO}_{2}-\mathrm{N} 25$ or $\mathrm{TiO}_{2}-\mathrm{A} 60$ at concentrations of $0,0.1,1,10$ and $100 \mu \mathrm{g} \mathrm{mL} \mathrm{m}^{-1}$ for 24,48 and 72 h. Fig. 3A and B illustrates the results of the LDH assay, showing each treatment at various administered doses and times. The A549 cells experienced a significant increase of cell death after exposure to $\mathrm{TiO}_{2}-\mathrm{N} 25$ at concentrations of 1-100 $\mu \mathrm{g}$ $\mathrm{mL}^{-1}$ for $24 \mathrm{~h}$ (Fig. 3A, $P<0.05$ ). The effects of $\mathrm{TiO}_{2}-\mathrm{N} 25$ on the A549 cells were more prominent after $48 \mathrm{~h}$ and $72 \mathrm{~h}$ than after
24 h (Fig. 3A, $P<0.01$ ). Compared with the control, treatment with $\mathrm{TiO}_{2}$-A60 significantly increased the cytotoxicity against A549 cells at $0.1-100 \mu \mathrm{g} \mathrm{mL}^{-1}$ after $48 \mathrm{~h}$ and $72 \mathrm{~h}$ of exposure $(P$ $<0.01)$. For the $16 \mathrm{HBE}$ cell line, the $\mathrm{TiO}_{2} \mathrm{NPs}$ were cytotoxic only at higher concentrations and longer treatment times, as shown in Fig. 3B. It is evident from Fig. 3B that the $16 \mathrm{HBE}$ cells were less sensitive to $\mathrm{TiO}_{2}$-N25 than the A549 cells were, as higher concentrations were required for cytotoxic effects after $24 \mathrm{~h}$ treatment. Nevertheless, the $\mathrm{TiO}_{2}-\mathrm{N} 25$ particles were more toxic against both cell lines than $\mathrm{TiO}_{2}$-A60. In the subsequent experiments, treatments were performed with $\mathrm{TiO}_{2} \mathrm{NPs}$ at 0 , $0.1,1,10$ and $100 \mu \mathrm{g} \mathrm{mL}^{-1}$ for $48 \mathrm{~h}$.

\section{Effects of $\mathrm{TiO}_{2} \mathrm{NP}$ exposure on ROS synthesis}

After exposure to $\mathrm{TiO}_{2} \mathrm{NP}$ or co-treatment with NAC, the levels of intracellular ROS in the A549 and 16HBE cells were determined using the fluorescent ROS indicator DCFH-DA. The levels of intracellular ROS in the A549 cells were found markedly increased at 10-100 $\mu \mathrm{g} \mathrm{mL}^{-1}$ compared with the control (Fig. 4A and $\mathrm{B}, P<0.01)$. Quantification data demonstrated that the intensity of DCFH-DA fluorescence (representing the intracellular ROS level) in the $16 \mathrm{HBE}$ cells were significantly increased at 1-100 $\mu \mathrm{g} \mathrm{mL}^{-1}$ compared with the control (Fig. $4 \mathrm{~A}$ and $\mathrm{C}$ ). These results indicated that $\mathrm{TiO}_{2}$ NPs induced ROS accumulation in the A549 and 16HBE cells. Statistical analysis of the DCFH-DA fluorescence levels of cells co-treatment with NAC demonstrated that NAC significantly reduced the $\mathrm{TiO}_{2}$ NPinduced ROS accumulation (Fig. 4A-C).

Besides, the anti-oxidant NAC was used to test whether $\mathrm{TiO}_{2}$ NPs increased cell death via inducing ROS accumulation. As shown in Fig. 4D and E, co-treatment with NAC abolished $\mathrm{TiO}_{2}$ 
A

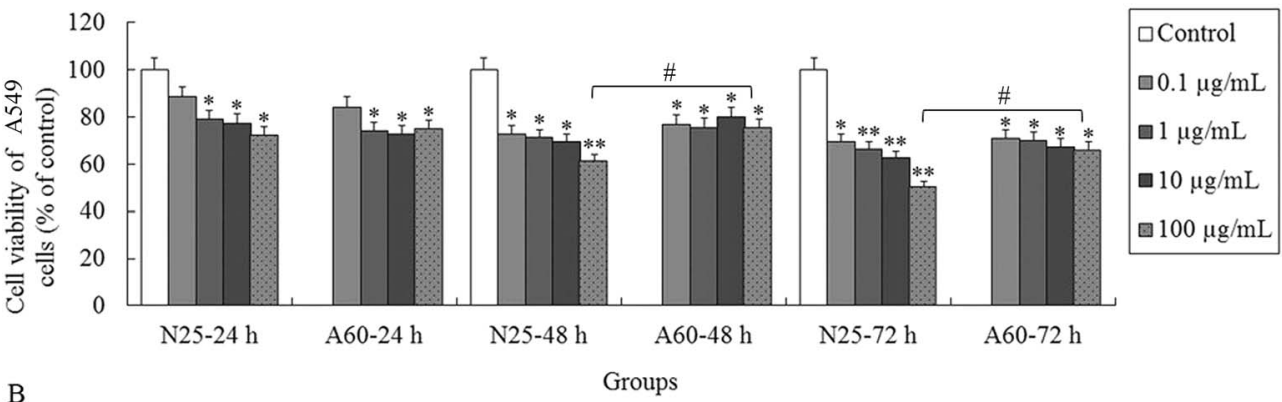

B

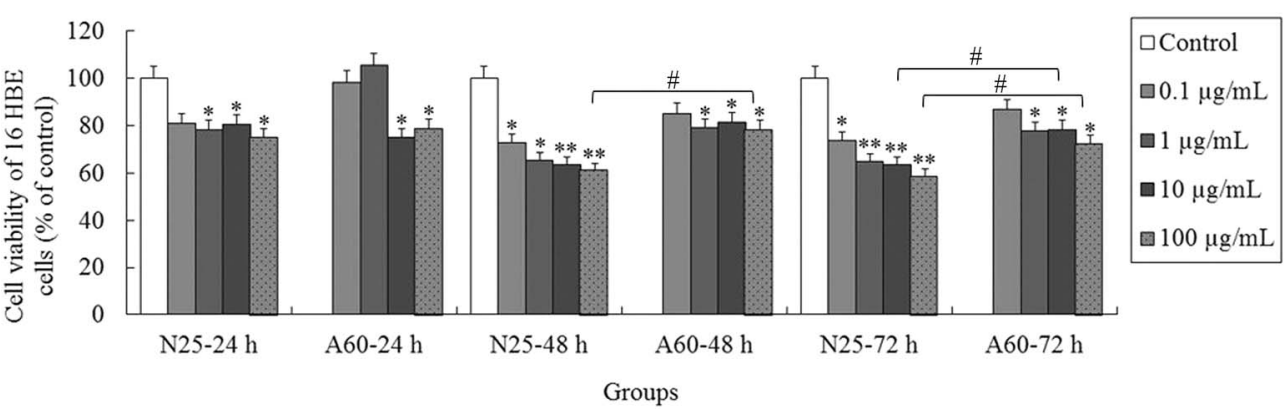

Fig. 2 Cell viability was assessed by MTT analysis after the $16 \mathrm{HBE}$ and $\mathrm{A} 549$ cells were treated with $\mathrm{TiO}_{2} \mathrm{NPs}$ (particle sizes of $25 \mathrm{~nm}$ and $60 \mathrm{~nm}$, concentrations of 0.1-100 $\mathrm{g} \mathrm{mL}^{-1}$ ), or culture medium as the control, for 24, 48 or $72 \mathrm{~h}$. (A) Cell viability of A549 cells after treated with TiO $2^{-}$ $\mathrm{N} 25$ and $\mathrm{TiO}_{2}-\mathrm{A} 60$. (B) Cell viability of $16 \mathrm{HBE}$ cells after treated with $\mathrm{TiO}_{2}-\mathrm{N} 25$ and $\mathrm{TiO}_{2}-\mathrm{A} 60$. Results are expressed as cell viability relative to control. Data from three independent experiments are expressed as means $\pm \mathrm{SD}(n=3)$. Error bars indicate standard deviation of three samples. $*, P<0.05$ and **, $P<0.01$ compared with controls. \#, statistically different between each other $P<0.05$.

A

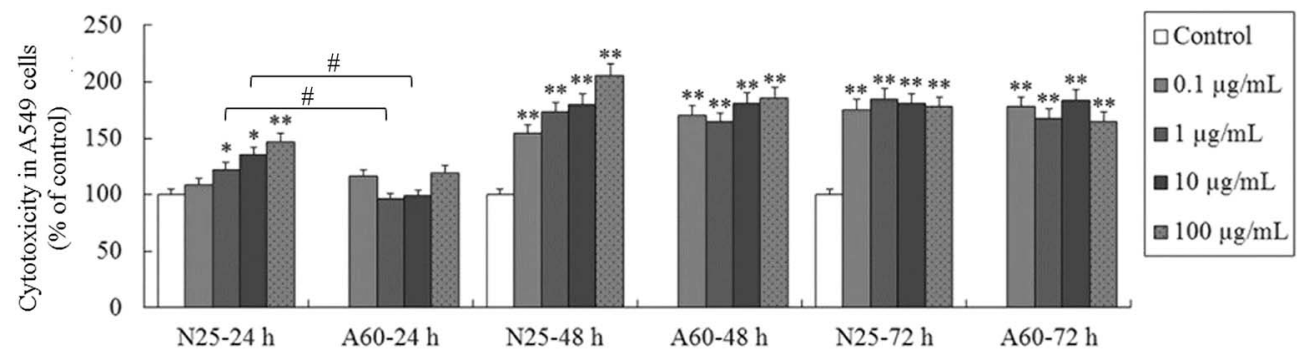

$\mathrm{B}$

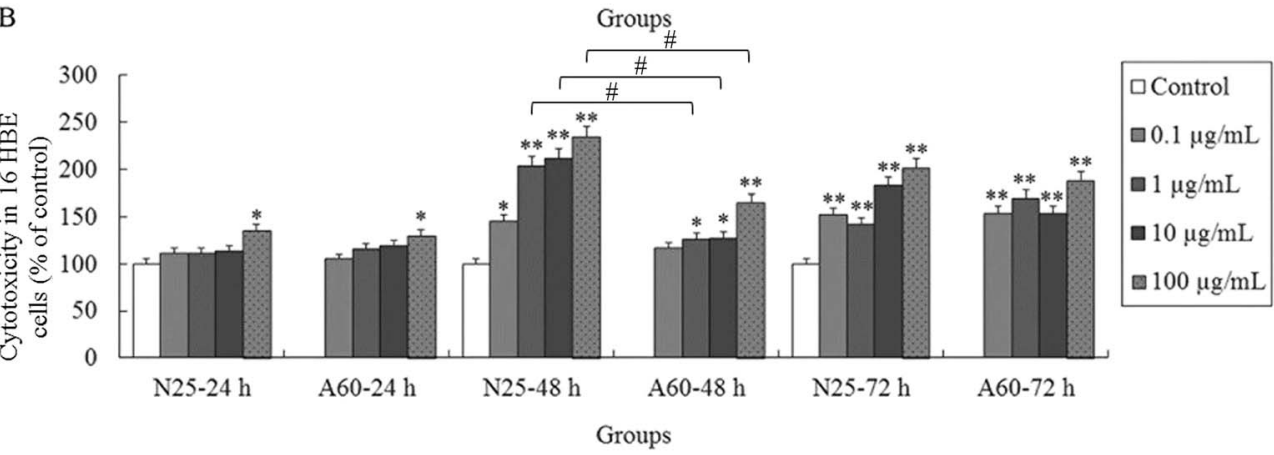

Fig. 3 Cytotoxicity in $16 \mathrm{HBE}$ and A549 cells relative to control determined using LDH assay following exposure to TiO $\mathrm{NPs}_{2}$ (particle sizes of $25 \mathrm{~nm}$ and $60 \mathrm{~nm}$, concentrations of $0.1-100 \mu \mathrm{g} \mathrm{mL}^{-1}$ ) for 24,48 or $72 \mathrm{~h}$. (A) Cytotoxicity in $\mathrm{A} 549$ cells after treated with $\mathrm{TiO}_{2}-\mathrm{N}_{25}$ and TiO ${ }_{2}-\mathrm{A}_{60}$. (B) Cytotoxicity in $16 \mathrm{HBE}$ cells after treated with $\mathrm{TiO}_{2}-\mathrm{N} 25$ and $\mathrm{TiO}_{2}-\mathrm{A} 60$. Results are expressed as cytotoxicity relative to control. Data from three independent experiments are expressed as means $\pm \mathrm{SD}(n=3)$. Error bars indicate standard deviation of three samples. *, $P<0.05$ and **, $P$ $<0.01$ compared with controls. \#, statistically different between each other $P<0.05$. 
A
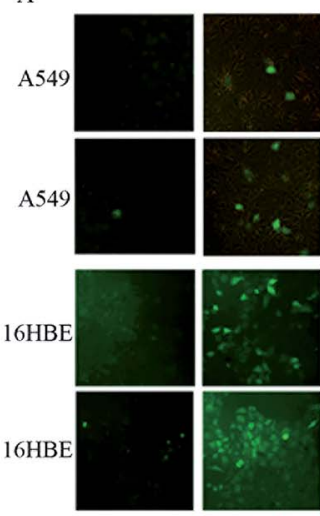

Control

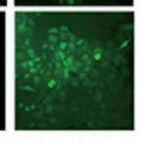

$0.1 \mu \mathrm{g} / \mathrm{mL}$
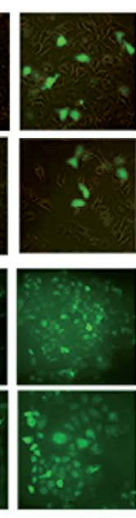

$1 \mu \mathrm{g} / \mathrm{mL}$
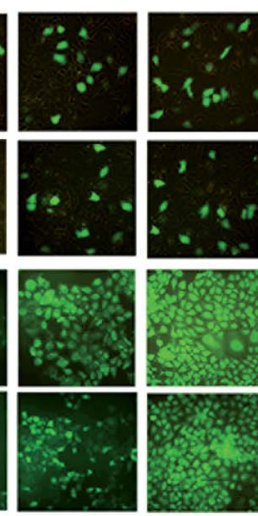

$10 \mu \mathrm{g} / \mathrm{mL}$

$100 \mu \mathrm{g} / \mathrm{mL}$
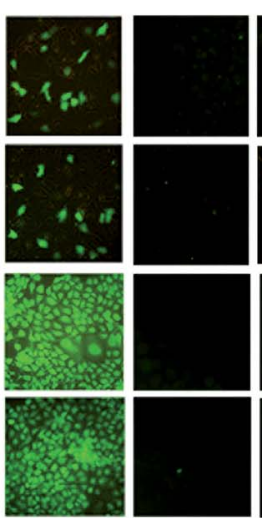

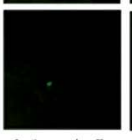

$0.1 \mu \mathrm{g} / \mathrm{mL}$
$+\mathrm{NAC}$
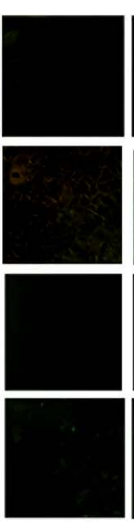

$1 \mu \mathrm{g} / \mathrm{mL}$
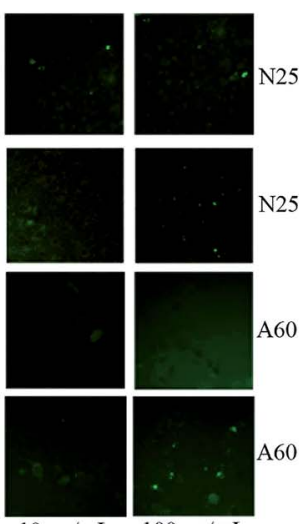

$10 \mu \mathrm{g} / \mathrm{mL}$
$+\mathrm{NAC}$

$+\mathrm{NAC}+\mathrm{NAC}$

B

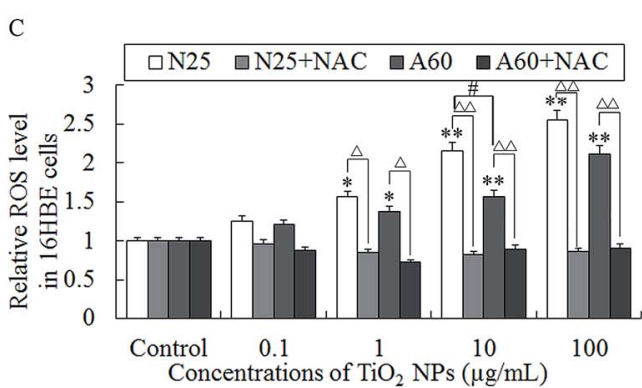

D
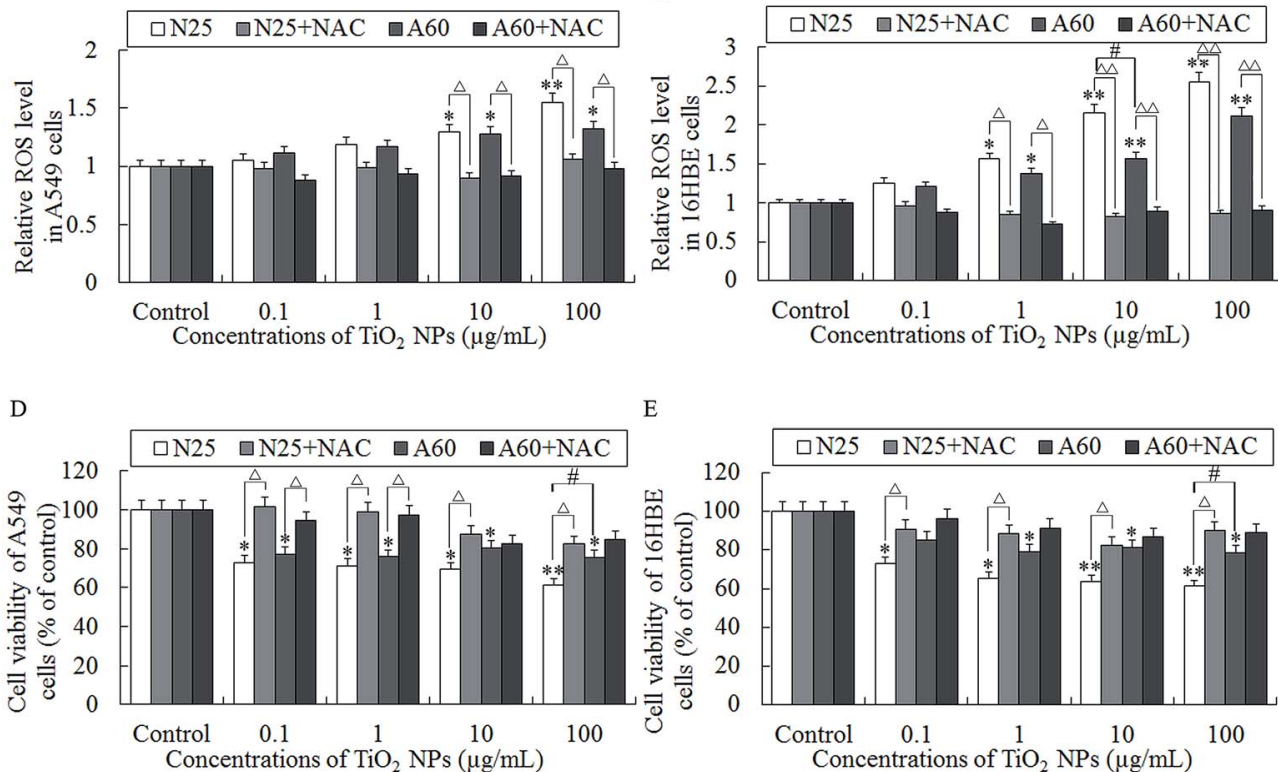

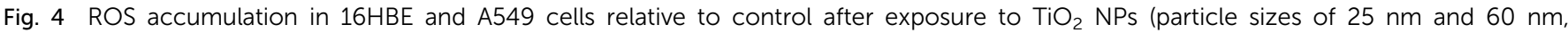

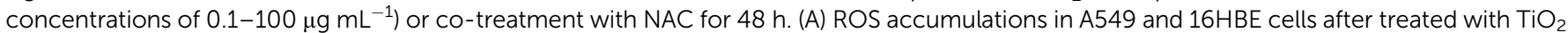

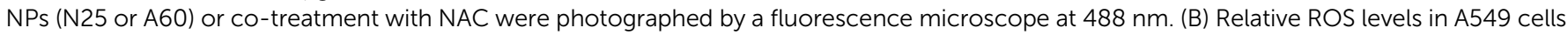

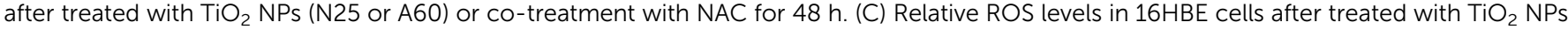

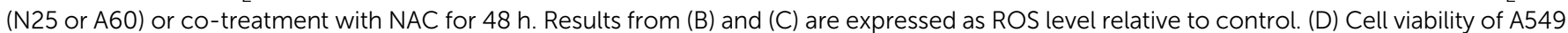

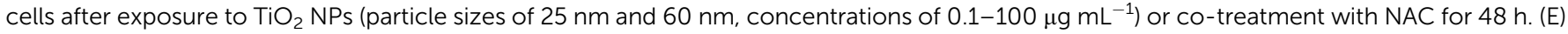

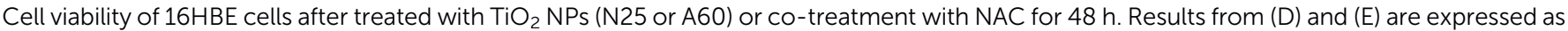

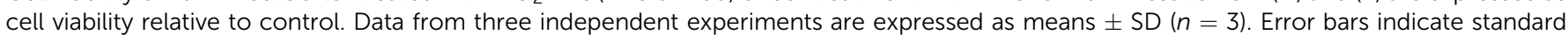

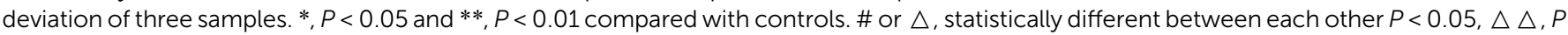
$<0.01$ compared with controls.

NP-induced cell death as determined by MTT which was consistent with the effect of NAC of reducing the levels of $\mathrm{TiO}_{2}$ NPs-induced ROS. Taken together, this study suggested that $\mathrm{TiO}_{2}$ NPs induced cell death mainly via a ROS-dependent mechanism.

\section{Effects of $\mathrm{TiO}_{2} \mathrm{NP}$ exposure on genomic DNA methylation}

The degree of genomic DNA methylation of the A549 and 16HBE cells was determined after treatment with different concentrations of $\mathrm{TiO}_{2}-\mathrm{N} 25$ or $\mathrm{TiO}_{2}-\mathrm{A} 60$ for $48 \mathrm{~h}$. As shown in Fig. 5A, the genomic DNA methylation levels of the A549 cells were reduced after exposure to $\mathrm{TiO}_{2}-\mathrm{N} 25$ at $0.1-100 \mu \mathrm{g} \mathrm{mL} \mathrm{mL}^{-1}$ compared with the control $(P<0.01)$. After exposure to $\mathrm{TiO}_{2}-\mathrm{A} 60$, at all concentrations in the range $0.1-100 \mu \mathrm{g} \mathrm{mL}^{-1}$, the extent of DNA methylation in the A549 cells decreased significantly (hypomethylation) compared with the control (Fig. 5A, $P<0.05$ ). The obtained results thus indicated that $\mathrm{TiO}_{2}$ NPs exposure induced a significant decrease of genomic DNA methylation in A549 cells. Fig. 5B shows that for the $16 \mathrm{HBE}$ cells, the global DNA methylation levels decreased after exposure to $\mathrm{TiO}_{2}-\mathrm{N} 25$ at 100 $\mu \mathrm{g} \mathrm{mL} \mathrm{m}^{-1}$, compared with the control $(P<0.01)$. Moreover, for treatment with $\mathrm{TiO}_{2}-\mathrm{A} 60$, the genomic DNA methylation levels 
A

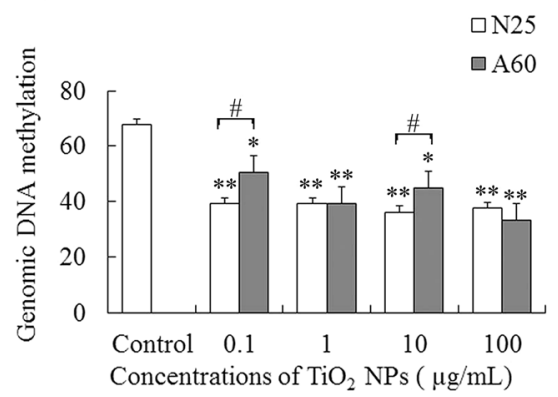

B

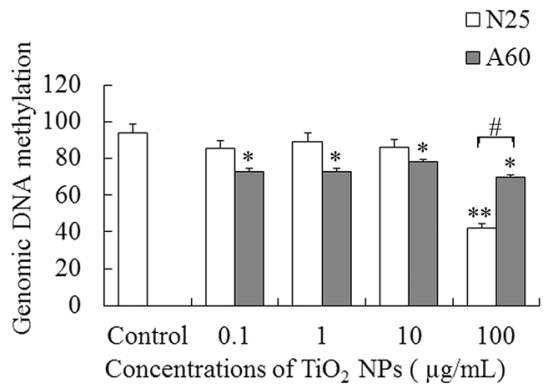

Fig. 5 Genomic DNA methylation levels of A549 and 16HBE cells after treatment with different concentrations of TiO 2 NPs (particle sizes of $25 \mathrm{~nm}$ and $60 \mathrm{~nm}$, concentrations of $0.1-100 \mu \mathrm{g} \mathrm{mL}{ }^{-1}$ ) for $48 \mathrm{~h}$. (A) Genomic DNA methylation levels in A549 after treated with TiO $2-\mathrm{N}_{2} 5$ and $\mathrm{TiO}_{2}-\mathrm{A} 60$. (B) Genomic DNA methylation levels in $16 \mathrm{HBE}$ cells after treated with $\mathrm{TiO}_{2}-\mathrm{N} 25$ and $\mathrm{TiO}_{2}-\mathrm{A} 60$. Data from three independent experiments are expressed as means $\pm \mathrm{SD}(n=3)$. Error bars indicate standard deviation of three samples. *, $P<0.05$ and **, $P<0.01$ compared with controls. \#, statistically different between each other $P<0.05$.

of the $16 \mathrm{HBE}$ cells were significantly decreased by all concentrations in the range $0.1-100 \mu \mathrm{g} \mathrm{mL} \mathrm{m}^{-1}$ (Fig. 5B, $P<0.05$ ).

\section{Effects of $\mathrm{TiO}_{2} \mathrm{NP}$ exposure on expression of $\mathrm{Dnmt3b}$, $M b d 2$ and TETs in A549 and $16 \mathrm{HBE}$ cells}

To investigate the possible mechanisms of the genomic DNA hypomethylation observed after exposure to $\mathrm{TiO}_{2} \mathrm{NPs}$, we further examined the expression levels of $D n m t 3 b, M b d 2$ and TETs in the A549 and 16HBE cells.

As shown in Fig. 6A, C and J, the mRNA expression levels of Dnmt3b, Mbd2 and Tet3 decreased in the A549 cells after exposure to $\mathrm{TiO}_{2}-\mathrm{N} 25$ at $0.1-100 \mu \mathrm{g} \mathrm{mL}^{-1}(P<0.01)$. The mRNA expression levels of Tet 1 and Tet2 decreased in the A549 cells after exposure to $\mathrm{TiO}_{2}-\mathrm{N} 25$ at $1-100 \mu \mathrm{g} \mathrm{mL}^{-1}$ (Fig. $6 \mathrm{E}$ and $\mathrm{G}, P<$ 0.01). $\mathrm{TiO}_{2}-\mathrm{A} 60$ reduced the mRNA expression levels of Dnmt3b, Mbd2, Tet2 and Tet3 in the A549 cells at $0.1-100 \mu \mathrm{g} \mathrm{mL}^{-1}$ (Fig. 6B, D, H and K, $P<0.01$ ). The mRNA expression levels of Tet1 decreased in the A549 cells after exposure to $\mathrm{TiO}_{2}-\mathrm{A} 60$ at 1$100 \mu \mathrm{g} \mathrm{mL}^{-1}$ (Fig. 6F, $P<0.01$ ).

Interestingly, in the $16 \mathrm{HBE}$ cells, exposure to $\mathrm{TiO}_{2}-\mathrm{N} 25$ or $\mathrm{TiO}_{2}$-A60 (0.1-100 $\left.\mu \mathrm{g} \mathrm{mL}^{-1}\right)$ had different (mostly opposite) effects on the expression of Dnmt3b, Mbd2, Tet1, Tet2 and Tet3 compared with the A549 cells (Fig. 7A-K). Exposure to $\mathrm{TiO}_{2}-\mathrm{N} 25$ caused an increase in the expression of Dnmt $3 b$, Tet1, Tet 2 and Tet 3 in the $16 \mathrm{HBE}$ cells relative to the untreated cells (Fig. 7A, E, $\mathrm{G}$ and J). Only the expression of $\mathrm{Mbd} 2$ was reduced in the $16 \mathrm{HBE}$ cells after exposure to $\mathrm{TiO}_{2}-\mathrm{N} 25$, and only at relatively high concentrations (10-100 $\mu \mathrm{g} \mathrm{mL}^{-1}$ ), as shown in Fig. 7C. Likewise, in the $\mathrm{TiO}_{2}$-A60 exposure groups, the expression of $\mathrm{Mbd2}$, Tet1, Tet2 and Tet 3 increased in the $16 \mathrm{HBE}$ cells (Fig. 7D, F, H and K).

Based on these results, we hypothesised that the changes in expression levels of Dnmt $3 b, M b d 2$ and TETs may be associated with $\mathrm{TiO}_{2}$ NPs-induced genomic hypomethylation in the A549 and $16 \mathrm{HBE}$ cells.

\section{Effects of $\mathrm{TiO}_{2} \mathrm{NP}$ exposure on the expression levels of DNMT3B and MBD2 proteins}

As shown in Fig. 8A and C, treatment of $\mathrm{TiO}_{2}$ NPs significantly reduced the levels of DNMT3B in A549 cells in a dose-dependent manner when compared with control $(P<0.05)$. The expression levels of MBD2 proteins were significantly decreased after $\mathrm{TiO}_{2}$ $\mathrm{N} 25$-treatment at concentrations of $0.1,1$, and $100 \mu \mathrm{g} \mathrm{mL}{ }^{-1}$ and at concentrations of $10-100 \mu \mathrm{g} \mathrm{mL}^{-1}$ in the $\mathrm{TiO}_{2}$-A60 group $(P<$ 0.05 , Fig. 8A and D).

In the $16 \mathrm{HBE}$ cells, exposure to $\mathrm{TiO}_{2}-\mathrm{N} 25$ caused an increase in the expression of DNMT3B at relatively high concentrations (10$\left.100 \mu \mathrm{g} \mathrm{mL}{ }^{-1}\right)$ which was opposite to the A549 cells $(P<0.05$, Fig. 8B and $\mathrm{E})$. And in the $\mathrm{TiO}_{2}-\mathrm{A} 60$ groups, the MBD2 proteins were decreased at concentrations of $10-100 \mu \mathrm{g} \mathrm{mL} \mathrm{mL}^{-1}(P<0.01$, Fig. $8 \mathrm{~B}$ and $\mathrm{E})$. However, the expression of MBD2 proteins were decreased after exposure to $\mathrm{TiO}_{2}$-N25 only at the highest concentration (100 $\mu \mathrm{g} \mathrm{mL}^{-1}$ ) and were increased in the $\mathrm{TiO}_{2}$-A60 groups at concentrations of $1-100 \mu \mathrm{g} \mathrm{mL} \mathrm{m}^{-1}$, as shown in Fig. $8 \mathrm{~B}$ and $\mathrm{F}$.

\section{Discussion}

This study evaluated the potential toxicity of varying doses of $\mathrm{TiO}_{2}$ NPs on human respiratory cells. The alveolar epithelium and bronchial epithelial cells make direct contact with inhaled nanoparticles, so we chose two cell lines as in vitro models of this contact. ${ }^{\mathbf{1 1 2 5}}$ The viability, membrane integrity, intracellular ROS and genomic DNA methylation of the cell lines, as well as their expression of methylation-related genes and proteins, were measured after exposure to two types of $\mathrm{TiO}_{2}$ NPs: those with particle sizes of $25 \mathrm{~nm}$ (nanotube crystalline phase) or $60 \mathrm{~nm}$ (anatase crystalline phase).

Both types of $\mathrm{TiO}_{2}$ NPs were characterised physicochemically before the exposure experiments. In MEM and RPMI 1640, the surface charge on the $\mathrm{TiO}_{2}$ NPs was less negative than in water. The decrease in charge was caused by a partial compensation of the negative charges by inorganic cations attracted to the surfaces of the $\mathrm{TiO}_{2}$ NPs in the cell culture media. ${ }^{26}$ The $\mathrm{TiO}_{2}-\mathrm{N} 25$ particles retained more negative surface charge than $\mathrm{TiO}_{2}-\mathrm{A} 60$. The relatively low zeta potentials of the particles reduced the stability of their nanodispersions, causing them to aggregate. The particles had greater hydrodynamic diameters in cell culture media than in water due to this enhanced aggregation. However, it has been reported that even 
A

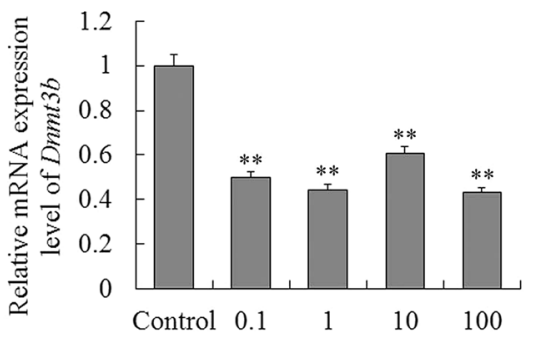

Concentrations of $\mathrm{TiO}_{2}-\mathrm{N} 25(\mu \mathrm{g} / \mathrm{mL})$

$$
\mathrm{C}
$$

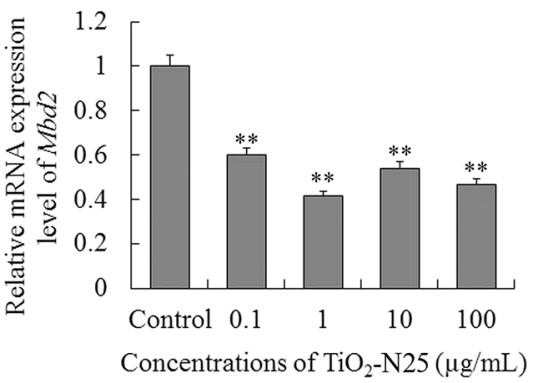

E

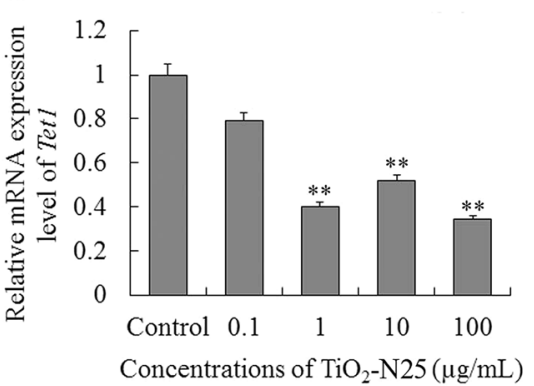

G

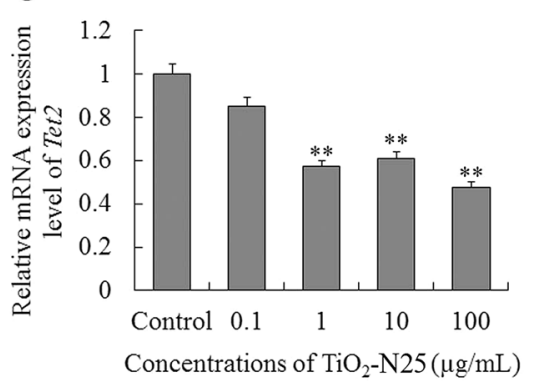

J

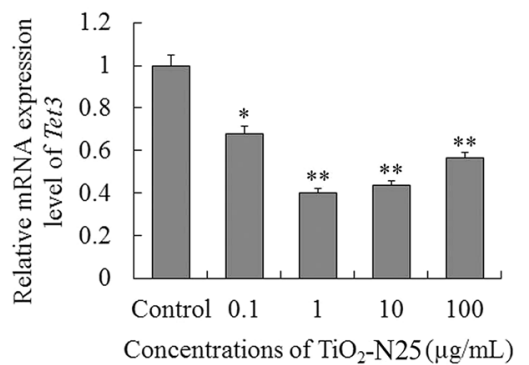

B

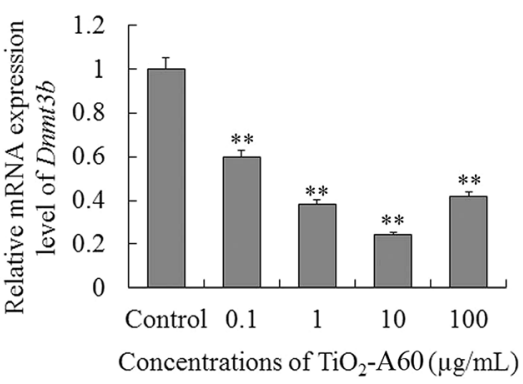

D

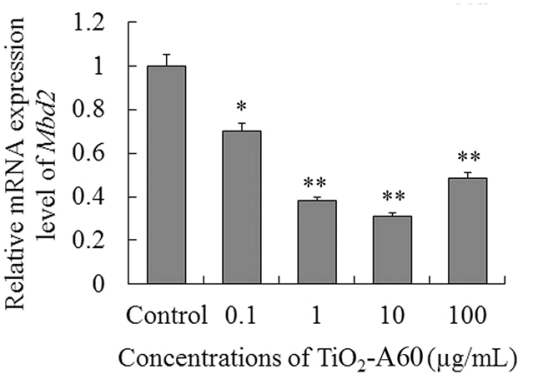

F
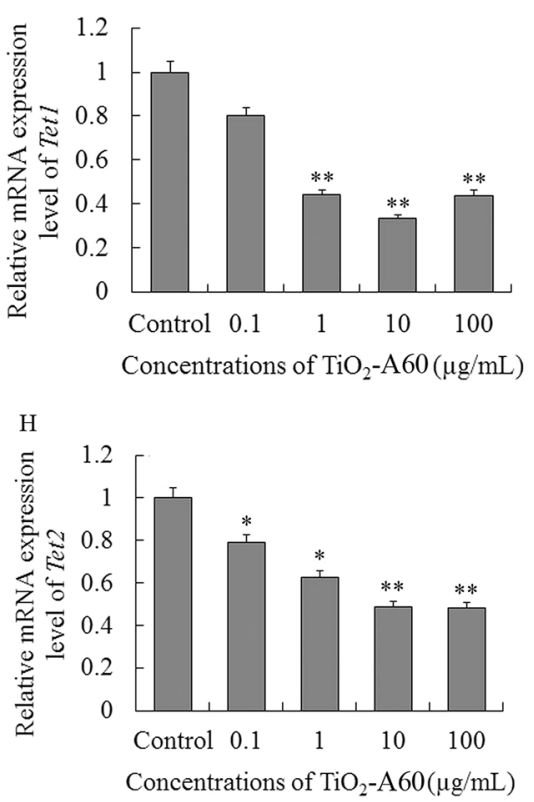

K

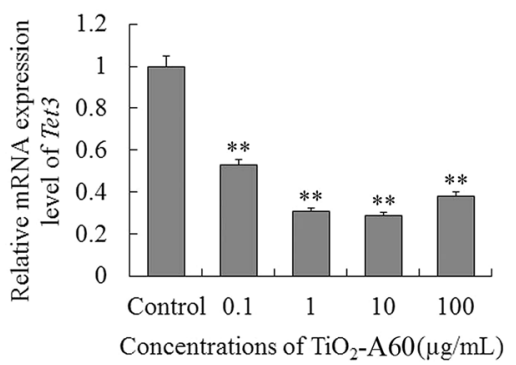

Fig. 6 Effects of exposure to $\mathrm{TiO}_{2} \mathrm{NPs}$ (particle sizes of $25 \mathrm{~nm}$ and $60 \mathrm{~nm}$, concentrations of $0.1-100 \mu \mathrm{gl}^{-1}$ ) for $48 \mathrm{~h}$ on mRNA expression of Dnmt3b, Mbd2 and TETs in A549 cells. Relative mRNA expression level of Dnmt3b, Mbd2 and Tet1-3 after exposure to TiO $2-\mathrm{N}_{25}$ (A, C, E, G and J) and $\mathrm{TiO}_{2}-\mathrm{A} 60$ (B, D, F, H and K). Results are expressed as cytotoxicity relative to control. Data from three independent experiments are expressed as means $\pm \mathrm{SD}(n=3)$. Error bars indicate standard deviation of three samples. $*, P<0.05$ and $* *, P<0.01$ compared with controls. 

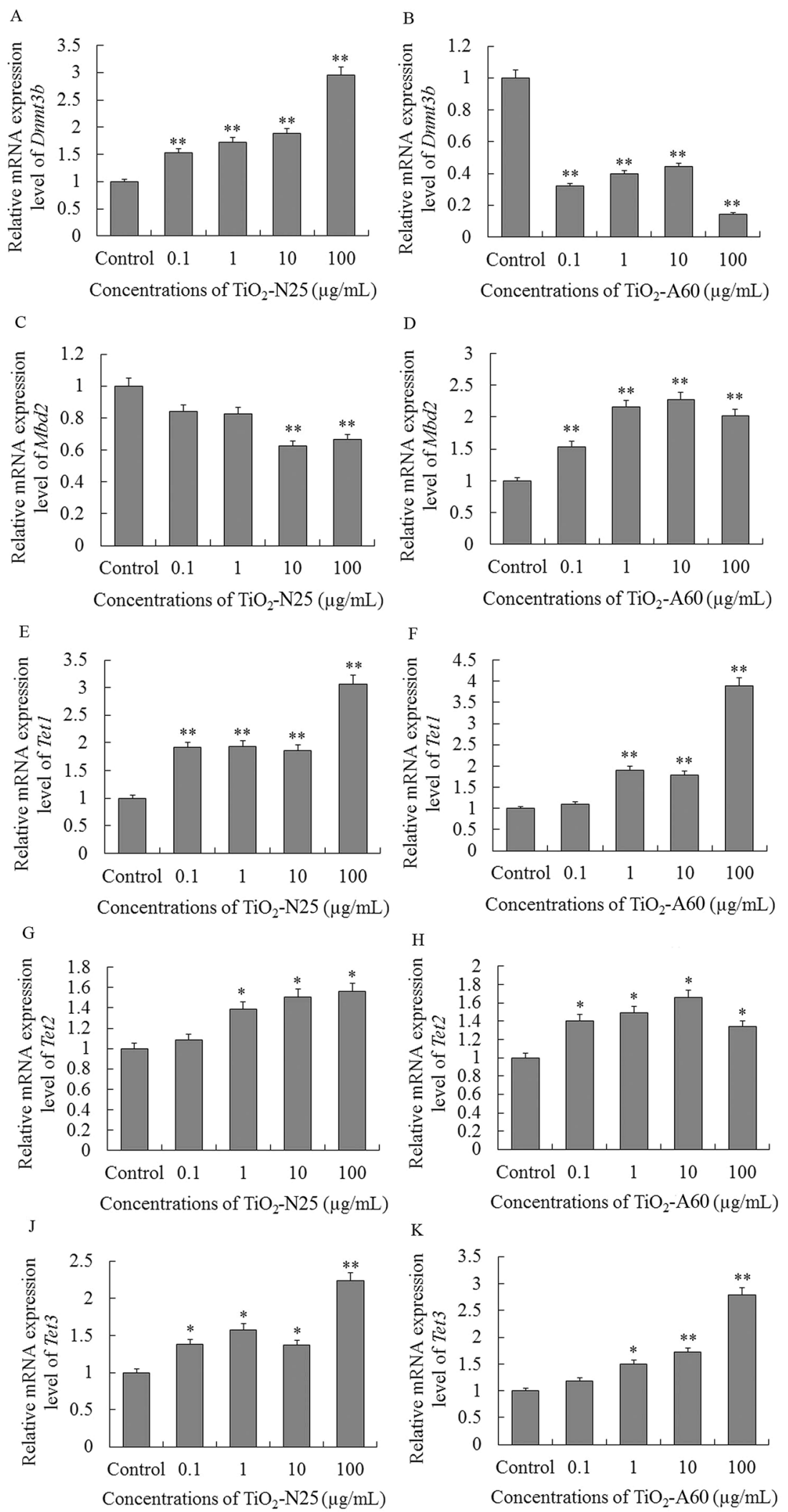

Fig. 7 Effects of exposure to $\mathrm{TiO}_{2} \mathrm{NPs}$ (particle sizes of $25 \mathrm{~nm}$ and $60 \mathrm{~nm}$, concentrations of $0.1-100 \mu \mathrm{gl}^{-1}$ ) for $48 \mathrm{~h}$ on mRNA expression of Dnmt3b, Mbd2 and TETs in 16HBE cells. Relative mRNA expression level of Dnmt3b, Mbd2 and Tet1-3 after exposure to TiO $2-\mathrm{N} 25$ (A, C, E, G and J) and $\mathrm{TiO}_{2}-\mathrm{A} 60$ (B, D, F, H and K). Results are expressed as cytotoxicity relative to control. Data from three independent experiments are expressed as means $\pm \mathrm{SD}(n=3)$. Error bars indicate standard deviation of three samples. *, $P<0.05$ and $* *, P<0.01$ compared with controls. 
A

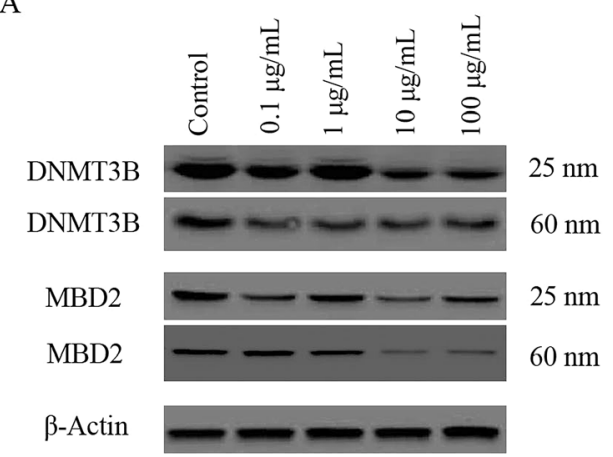

C

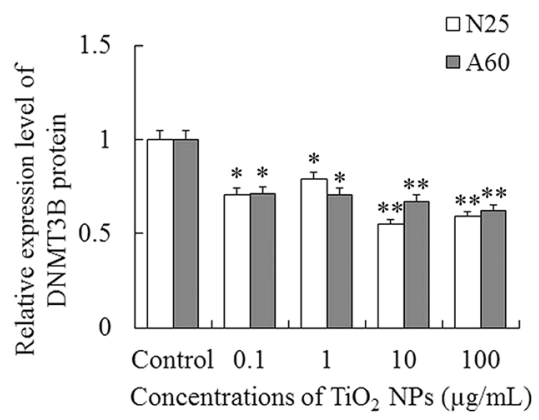

E

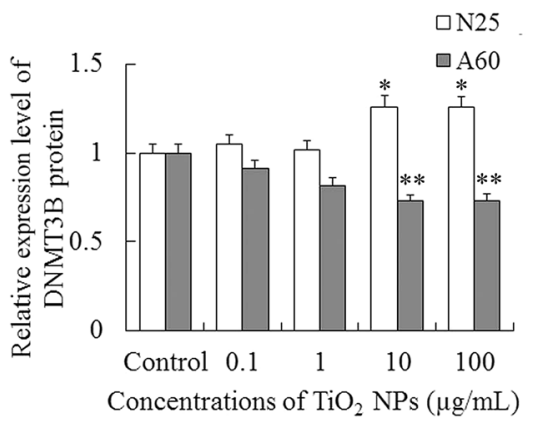

B

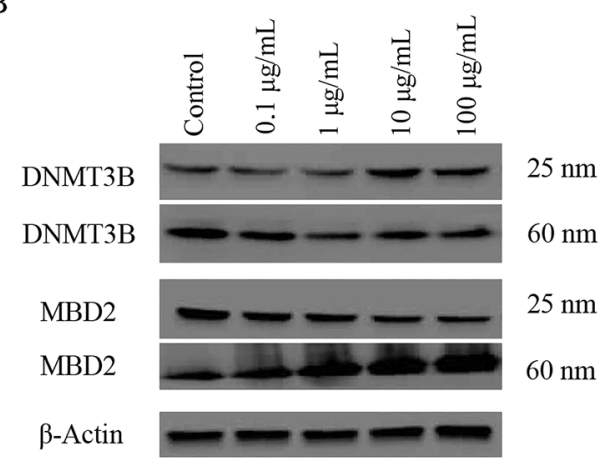

D

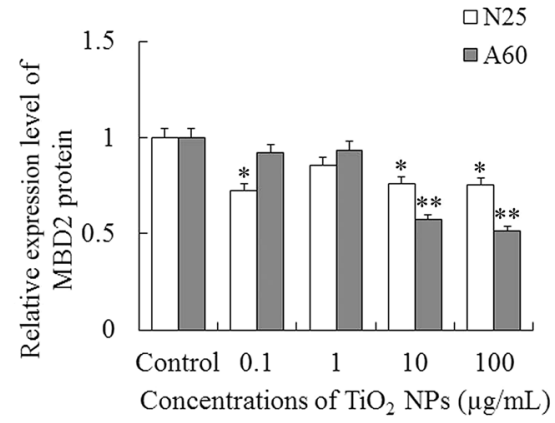

F

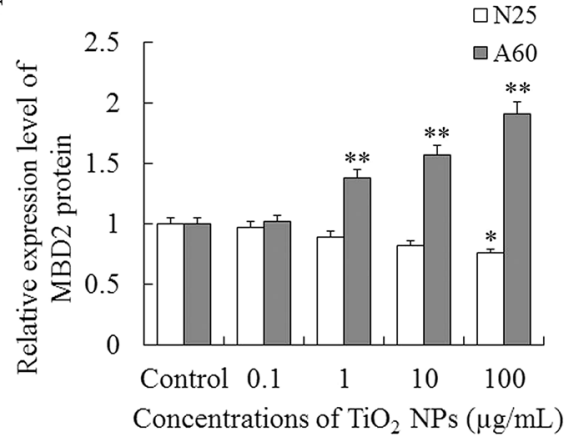

Fig. 8 Effects of exposure to $\mathrm{TiO}_{2} \mathrm{NPs}$ (particle sizes of $25 \mathrm{~nm}$ and $60 \mathrm{~nm}$, concentrations of $0.1-100 \mu \mathrm{g} \mathrm{mL} \mathrm{L}^{-1}$ ) for $48 \mathrm{~h}$ on expression of DNMT3B and MBD2 proteins in A549 and 16HBE cells. (A), (C) and (D) Relative expression level of DNMT3B and MBD2 in A549 cells. B, E and F Relative expression level of DNMT3B and MBD2 in 16HBE cells. Results are expressed as cytotoxicity relative to control. Data from three independent experiments are expressed as means $\pm \mathrm{SD}(n=3)$. Error bars indicate standard deviation of three samples. *, $P<0.05$ and $* *, P<$ 0.01 compared with controls.

in the form of aggregates, the cytotoxic effects of nanoparticles depend on the primary particle size and surface area. ${ }^{27}$

The viability and membrane integrity of both cell lines were negatively affected by treatment with $\mathrm{TiO}_{2}-\mathrm{N} 25$ or $\mathrm{TiO}_{2}-\mathrm{A} 60$. For both cell lines, the decrease in cell viability after exposure to $\mathrm{TiO}_{2}$ NPs was stronger for higher treatment concentrations, longer treatment times and smaller particle sizes. A previous study demonstrated that $\mathrm{TiO}_{2}$ NPs with diameters of $5 \mathrm{~nm}$ inhibited the proliferation of A549 cells in a dose- and timedependent manner. ${ }^{28}$ In addition, the cytotoxicity results in this study suggested that A549 cells were more sensitive to exposure to $\mathrm{TiO}_{2}-\mathrm{N} 25$ than were $16 \mathrm{HBE}$ cells. This agrees with an earlier study showing that although $\mathrm{TiO}_{2} \mathrm{NPs}$ with diameters of $21 \mathrm{~nm}$ were cytotoxic for both A549 and 16HBE cell lines at relatively high concentrations, A549 cells were more sensitive than $16 \mathrm{HBE}$ cells. ${ }^{11}$ The influence of size on the toxicity of $\mathrm{TiO}_{2}$ NPs has been further reported elsewhere. ${ }^{29,30}$ The cytotoxic effects of $\mathrm{TiO}_{2}$ NPs exposure on A549 and 16HBE cells evidently impair their normal functioning. More detailed mechanistic studies are needed to clarify the cellular responses to $\mathrm{TiO}_{2} \mathrm{NPs}$ exposure.

$\mathrm{TiO}_{2}$ NPs possesses toxicity has been proofed, but the underlying mechanisms of which remain elusive. Disturbances in oxidative stress state of cells can cause toxic effects that damage all components of the cell, including proteins, lipids, and DNA. Oxidative stress causes base damage, which is mostly caused by ROS generated. Increased intracellular ROS accumulation has been shown to induce cell death. As demonstrated 
in a previous study, $\mathrm{TiO}_{2}(15 \mathrm{~nm})$ NPs induces increased intracellular ROS in bronchial epithelial cells (16HBE14o-cell line and primary cells). ${ }^{10}$ In this study, the levels of intracellular ROS in the A549 and 16HBE cells were increased after exposure to $\mathrm{TiO}_{2}$ NP. Furthermore, the anti-oxidant NAC completely abolished the $\mathrm{TiO}_{2}$ NPs-induced ROS accumulation and cell death in both A549 and 16HBE cells. This study supports the concept that ROS accumulation plays a role the cytotoxicity of $\mathrm{TiO}_{2} \mathrm{NPs}$.

Although the potential adverse effects of $\mathrm{TiO}_{2}$ NPs have become more apparent in recent years, ${ }^{4}$ the epigenetic mechanisms responsible for the toxic effects of $\mathrm{TiO}_{2}$ NPs remain largely unknown. This work represents the first genome-wide study of DNA methylation in human respiratory cells treated with $\mathrm{TiO}_{2}$ NPs. We found that both $\mathrm{TiO}_{2}-\mathrm{N} 25$ and $\mathrm{TiO}_{2}-\mathrm{A} 60$ significantly reduced global DNA methylation levels in A549 and 16HBE cells. Moreover, the A549 cell line proved more sensitive to genomic DNA methylation by $\mathrm{TiO}_{2}$ NPs than did 16HBE cells. For the latter cell line, the epigenetic effects of $\mathrm{TiO}_{2}-\mathrm{A} 60$ were more significant than those of $\mathrm{TiO}_{2}-\mathrm{N} 25$. This observation is in line with previous studies reporting that anatase $\mathrm{TiO}_{2} \mathrm{NPs}$ exhibited more pronounced genotoxicity and deleterious effects, due to the photocatalytic properties of anatase $\mathrm{TiO}_{2}{ }^{25,30}$ Recently, exposure to various sources of particulate matter has been reported to affect DNA methylation. ${ }^{31-33}$ Consistent with our results, an in vitro study indicated that $\mathrm{TiO}_{2}$ particles of diameter $21 \mathrm{~nm}$ modestly affected DNA methylation in human small-airway epithelial cells (SAECs). ${ }^{22}$ Preliminary evidence has also been found that exposure to $\mathrm{TiO}_{2}$ nanotubes can regulate methylation levels in gene promoters. ${ }^{34}$ Global hypomethylation occurs early in tumorigenesis and predisposes cells to genomic instability and further genetic changes. ${ }^{35}$ DNA hypomethylation is associated with opening of the chromatin configuration and transcriptional activation, leading to chromosomal instability and aberrant expression of genes. ${ }^{36}$ Additionally, changes in global DNA methylation patterns have been shown to play a role in airway diseases. ${ }^{\mathbf{1 4 , 1 5}}$ Thus, we conclude that these alterations in global DNA methylation were associated with the cytotoxic effects of $\mathrm{TiO}_{2}$ NPs and might further contribute to the higher risk of respiratory diseases. In addition, the variation in the effects of different $\mathrm{TiO}_{2}$ NPs on different cell lines suggests that both the cell line sensibility and the nanoscale particle geometry affect the outcome.

As previously reported, analysis of global DNA methylation may mask the redistribution of hypomethylation and hypermethylation, which may result in cumulatively unchanged levels of global DNA methylation. ${ }^{33}$ Therefore, to further investigate the mechanism of global hypomethylation induced by $\mathrm{TiO}_{2}$ NPs, the expression levels of Dnmt3b, Mbd2 and TETs were determined in this study. In addition to changes in genomic DNA methylation, changes in the expression of DNA methylation-related genes were evident in both cell lines posttreatment with $\mathrm{TiO}_{2}$ NPs. In the A549 cells, the expression levels of Dnmt $3 b, M b d 2$ and TETs decreased after exposure to $\mathrm{TiO}_{2}$ NPs. However, in the $16 \mathrm{HBE}$ cell line, increased expression levels of Dnmt3b and TETs were observed in the $\mathrm{TiO}_{2}-\mathrm{N} 25$ groups, and of $\mathrm{Mbd} 2$ and TETs in the $\mathrm{TiO}_{2}-\mathrm{A} 60$ groups. Evidence indicates that DNMT3B can methylate hemimethylated and unmethylated $\mathrm{CpG}$ sites and also possesses maintenance functions. ${ }^{37,38} \mathrm{MBD} 2$, with its ability to bind to methylated DNA, can suppress transcription from methylated target gene promoters. MBD2 is also reported to function as a demethylase to activate transcription. ${ }^{39}$ 5-Methylcytosine $(5-\mathrm{mC})$ can be converted to 5-hydroxymethylcytosine $(5-\mathrm{hmC})$ by the TET proteins during DNA demethylation. ${ }^{19}$ Down-regulation of methyltransferases and $M b d 2$ at mRNA levels was previously reported after exposure to $\mathrm{SiO}_{2}$ nanoparticles, which were also associated with global hypomethylation. ${ }^{\mathbf{4 0}}$ The expression levels of DNA methyltransferases and Tet1 were reduced in alveolar macrophages after treatment with laser printer-emitted engineered nanoparticles. ${ }^{41}$ Moreover, significant losses in the expression of Tet1 were observed following $\mathrm{CuO}$ exposure in alveolar macrophages and SAEC cells. ${ }^{22,41}$ Consequently, the observed loss of Dnmt $3 b$ and $M b d 2$ expression may be the cause of the global hypomethylation in this study, implying that hypomethylation was the result of inhibitory effects on de novo DNA methylation by $\mathrm{TiO}_{2}$ NPs. Indeed, there is evidence that increased expression of $D n m t 3 b$ and $M b d 2$ acts as regulatory feedback in response to genomic hypomethylation. ${ }^{42,43}$ The alterations in TETs expression suggest the diminished ability of TETs to convert 5-mC into 5-hmC during demethylation. As shown by the western blot analyses, the expression levels of these proteins were consistent with the expression level of their mRNAs.

In summary, exposure to $\mathrm{TiO}_{2}$ NPs has the potential to trigger an unfavourable biological response in two cell lines relevant to the respiratory system. The negative effects of $\mathrm{TiO}_{2}$ NPs include a decrease in cell viability, a rise in cell death, genomic hypomethylation and altered expression of methylation-related genes, and may lead to increased risk of respiratory diseases in individuals exposed to $\mathrm{TiO}_{2}$ NPs. The different levels of cytotoxicity suggest a cell-specific sensitivity in addition to the influence of nanoparticle characteristics. While $\mathrm{TiO}_{2}$ NPs are weak mutagens, ${ }^{44}$ they may have detrimental effects on the expression of methylation-related genes, leading to alterations in the extent of DNA methylation. Importantly, we have shown that genomic hypomethylation and altered expression of DNA methylation-related genes may occur after exposure to low doses $\left(0.1 \mu \mathrm{g} \mathrm{mL}{ }^{-1}\right)$ of $\mathrm{TiO}_{2}$ NPs. Thus, our results indicated that both types of $\mathrm{TiO}_{2}$ NPs inhibited cell viability in a dose- and time-dependent manner. Moreover, the ability of $\mathrm{TiO}_{2}$ NPs to affect the cellular epigenome was demonstrated. The subsequent consequences of these altered epigenetic states remain unclear. Further investigations are needed to clarify the epigenomic effects of $\mathrm{TiO}_{2} \mathrm{NPs}$ in cells and more importantly in vivo. In addition, a broader range of diameters for each particle type of $\mathrm{TiO}_{2}$ NPs remains to be investigated in future research work. This may enable us to identify key factors to predict the toxicity of nanomaterials.

\section{Conclusion}

Our data indicate that $\mathrm{TiO}_{2}$ NPs can elicit unfavourable biological responses in vitro. Exposure to $\mathrm{TiO}_{2}$ NPs led to significant changes in cell viability, cell death, intracellular ROS, cell 
genomic DNA methylation and methylation-related gene and protein expression. Moreover, the observed dysfunction of DNA methylation suggests that $\mathrm{TiO}_{2}$ NPs exert effects on the cellular epigenome. To further investigate the mechanism of toxicity in detail, a study on murine responses to $\mathrm{TiO}_{2} \mathrm{NP}$ exposure via intratracheal instillation and whole-body inhalation is currently in progress.

\section{Author contributions}

Y. M. and Y. G. performed the experiments involving cell culture, cell viability, cell membrane integrity and intracellular ROS. Y. G. analysed the DNA methylation, gene and protein expressions in the cultured cells. Y. M., Y. G., S. W., Z. L. and Z. Q. carried out the analyses of data and the statistical tests. Y. M. designed the experiments and Y. G. drafted the manuscript. All authors approved the final version of the manuscript to be published.

\section{Conflict of interest}

None of the authors has any potential conflict of interest or financial interests to disclose.

\section{Acknowledgements}

This work was supported by funds from the National Natural Science Foundation of China (81072323, 81602831), China Postdoctoral Science Foundation funded project (2016M602537) and the Guangdong Provincial Science and Technology Project (2013B021800032).

\section{References}

1 A. Weir, P. Westerhoff, L. Fabricius, K. Hristovski and N. von Goetz, Environ. Sci. Technol., 2012, 46, 2242-2250.

2 X. X. Chen, B. Cheng, Y. X. Yang, A. Cao, J. H. Liu, L. J. Du, Y. Liu, Y. Zhao and H. Wang, Small, 2013, 9, 1765-1774.

3 Y. Morimoto, H. Izumi, Y. Yoshiura, T. Tomonaga, B. W. Lee, T. Okada, T. Oyabu, T. Myojo, K. Kawai, K. Yatera, M. Shimada, M. Kubo, K. Yamamoto, S. Kitajima, E. Kuroda, M. Horie, K. Kawaguchi and T. Sasaki, Nanotoxicology, 2016, 10, 607-618.

4 H. Shi, R. Magaye, V. Castranova and J. Zhao, Part. Fibre Toxicol., 2013, 10, 15.

5 B. Ekstrand-Hammarstrom, J. Hong, P. Davoodpour, K. Sandholm, K. N. Ekdahl, A. Bucht and B. Nilsson, Biomaterials, 2015, 51, 58-68.

6 J. Wang, G. Zhou, C. Chen, H. Yu, T. Wang, Y. Ma, G. Jia, Y. Gao, B. Li, J. Sun, Y. Li, F. Jiao, Y. Zhao and Z. Chai, Toxicol. Lett., 2007, 168, 176-185.

7 Y. Duan, J. Liu, L. Ma, N. Li, H. Liu, J. Wang, L. Zheng, C. Liu, X. Wang, X. Zhao, J. Yan, S. Wang, H. Wang, X. Zhang and F. Hong, Biomaterials, 2010, 31, 894-899.

8 H. W. Chen, S. F. Su, C. T. Chien, W. H. Lin, S. L. Yu, C. C. Chou, J. J. Chen and P. C. Yang, FASEB J., 2006, 20, 2393-2395.
9 A. S. Yazdi, G. Guarda, N. Riteau, S. K. Drexler, A. Tardivel, I. Couillin and J. Tschopp, Proc. Natl. Acad. Sci. U. S. A., 2010, 107, 19449-19454.

10 S. Hussain, L. C. Thomassen, I. Ferecatu, M. C. Borot, K. Andreau, J. A. Martens, J. Fleury, A. Baeza-Squiban, F. Marano and S. Boland, Part. Fibre Toxicol., 2010, 7, 10.

11 R. Guadagnini, K. Moreau, S. Hussain, F. Marano and S. Boland, Nanotoxicology, 2015, 9(1), 25-32.

12 L. Liu, Y. Li and T. O. Tollefsbol, Curr. Issues Mol. Biol., 2008, 10, 25-36.

13 J. Nicodemus-Johnson, K. A. Naughton, J. Sudi, K. Hogarth, E. T. Naurekas, D. L. Nicolae, A. I. Sperling, J. Solway, S. R. White and C. Ober, Am. J. Respir. Crit. Care Med., 2016, 193, 376-385.

14 D. Stefanowicz, T. L. Hackett, F. S. Garmaroudi, O. P. Gunther, S. Neumann, E. N. Sutanto, K. M. Ling, M. S. Kobor, A. Kicic, S. M. Stick, P. D. Pare and D. A. Knight, PLoS One, 2012, 7, e44213.

15 W. Qiu, A. Baccarelli, V. J. Carey, N. Boutaoui, H. Bacherman, B. Klanderman, S. Rennard, A. Agusti, W. Anderson, D. A. Lomas and D. L. DeMeo, Am. J. Respir. Crit. Care Med., 2012, 185, 373-381.

16 D. Rodenhiser and M. Mann, Can. Med. Assoc. J., 2006, 174, 341-348.

17 P. A. Jones, Nat. Rev. Genet., 2012, 13, 484-492.

18 K. D. Robertson, Nat. Rev. Genet., 2005, 6, 597-610.

19 S. Ito, L. Shen, Q. Dai, S. C. Wu, L. B. Collins, J. A. Swenberg, C. He and Y. Zhang, Science, 2011, 333, 1300-1303.

20 B. Hendrich and A. Bird, Mol. Cell. Biol., 1998, 18, 65386547.

21 S. V. Pirela, I. R. Miousse, X. Lu, V. Castranova, T. Thomas, Y. Qian, D. Bello, L. Kobzik, I. Koturbash and P. Demokritou, Environ. Health Perspect., 2016, 124, 210-219.

22 X. Lu, I. R. Miousse, S. V. Pirela, S. Melnyk, I. Koturbash and P. Demokritou, Nanotoxicology, 2015, 1-11.

23 M. Ghosh, S. Bhadra, A. Adegoke, M. Bandyopadhyay and A. Mukherjee, Mutat. Res., 2015, 774, 49-58.

24 J. Wang and Y. Fan, Int. J. Mol. Sci., 2014, 15, 22258-22278.

25 M. L. Jugan, S. Barillet, A. Simon-Deckers, N. Herlin-Boime, S. Sauvaigo, T. Douki and M. Carriere, Nanotoxicology, 2012, 6, 501-513.

26 L. C. Thomassen, A. Aerts, V. Rabolli, D. Lison, L. Gonzalez, M. Kirsch-Volders, D. Napierska, P. H. Hoet, C. E. Kirschhock and J. A. Martens, Langmuir, 2010, 26, 328-335.

27 S. Hussain, S. Boland, A. Baeza-Squiban, R. Hamel, L. C. Thomassen, J. A. Martens, M. A. Billon-Galland, J. Fleury-Feith, F. Moisan, J. C. Pairon and F. Marano, Toxicology, 2009, 260, 142-149.

28 Y. Wang, H. Cui, J. Zhou, F. Li, J. Wang, M. Chen and Q. Liu, Environ. Sci. Pollut. Res., 2015, 22, 5519-5530.

29 A. Simon-Deckers, B. Gouget, M. Mayne-L'hermite, N. Herlin-Boime, C. Reynaud and M. Carriere, Toxicology, 2008, 253, 137-146.

30 H. J. Johnston, G. R. Hutchison, F. M. Christensen, S. Peters, S. Hankin and V. Stone, Part. Fibre Toxicol., 2009, 6, 33. 
31 A. Baccarelli, R. O. Wright, V. Bollati, L. Tarantini, A. A. Litonjua, H. H. Suh, A. Zanobetti, D. Sparrow, P. S. Vokonas and J. Schwartz, Am. J. Respir. Crit. Care Med., 2009, 179, 572-578.

32 J. Madrigano, A. Baccarelli, M. A. Mittleman, R. O. Wright, D. Sparrow, P. S. Vokonas, L. Tarantini and J. Schwartz, Environ. Health Perspect., 2011, 119, 977-982.

33 I. R. Miousse, M. C. Chalbot, N. Aykin-Burns, X. Wang, A. Basnakian, I. G. Kavouras and I. Koturbash, Environ. Mol. Mutagen., 2014, 55, 428-435.

34 L. Lv, Y. Liu, P. Zhang, X. Zhang, J. Liu, T. Chen, P. Su, H. Li and Y. Zhou, Biomaterials, 2015, 39, 193-205.

35 P. W. Laird and R. Jaenisch, Annu. Rev. Genet., 1996, 30, 441464.

36 E. Daura-Oller, M. Cabre, M. A. Montero, J. L. Paternain and A. Romeu, Bioinformation, 2009, 3, 340-343.

37 T. Chen, Y. Ueda, J. E. Dodge, Z. Wang and E. Li, Mol. Cell. Biol., 2003, 23, 5594-5605.
38 I. Rhee, K. E. Bachman, B. H. Park, K. W. Jair, R. W. Yen, K. E. Schuebel, H. Cui, A. P. Feinberg, C. Lengauer, K. W. Kinzler, S. B. Baylin and B. Vogelstein, Nature, 2002, 416, 552-556.

39 M. Fatemi and P. A. Wade, J. Cell Sci., 2006, 119, 3033-3037. 40 C. Gong, G. Tao, L. Yang, J. Liu, Q. Liu and Z. Zhuang, Biochem. Biophys. Res. Commun., 2010, 397, 397-400.

41 X. Lu, I. R. Miousse, S. V. Pirela, J. K. Moore, S. Melnyk, I. Koturbash and P. Demokritou, Nanotoxicology, 2016, 10, 629-639.

42 Y. J. Wan, Y. Y. Li, W. Xia, J. Chen, Z. Q. Lv, H. C. Zeng, L. Zhang, W. J. Yang, T. Chen, Y. Lin, J. Wei and S. Q. Xu, Toxicology, 2010, 274, 57-64.

43 Y. Ma, W. Xia, D. Q. Wang, Y. J. Wan, B. Xu, X. Chen, Y. Y. Li and S. Q. Xu, Diabetologia, 2013, 56, 2059-2067.

44 K. Bhattacharya, M. Davoren, J. Boertz, R. P. Schins, E. Hoffmann and E. Dopp, Part. Fibre Toxicol., 2009, 6, 17. 